Kamila Lasocińska*

\title{
Autobiografia jako autokreacja. Twórcze aspekty procesu myślenia autobiograficznego $w$ edukacji dorosłych
}

Streszczenie: W swoim artykule zakładam, że aktywność autobiograficzna jest formą autokreacji. Wspomaganie myślenia autobiograficznego w edukacji dorosłych może wpływać na kształtowanie postaw twórczych wobec codziennych zadań i problemów. Elementy twórczości są obecne w aktywności autobiograficznej ze względu na możliwość różnych interpretacji tych samych wydarzeń życiowych. Te odmienne i różnorodne interpretacje mają charakter plastyczny i pomagają osobie w przekraczaniu własnych schematów myślowych. Ponadto proces konstruowania własnej historii życia opiera się na wykorzystywaniu „fantazji biograficznej” i elementów fikcji. Pozwala to na odnajdywanie różnych perspektyw własnej opowieści. Podczas procesu rekonstruowania historii życia jednostka kreuje własną tożsamość narracyjną, zakładając zmiany obrazu samej siebie zachodzące w czasie. Refleksyjny projekt własnej przyszłości oraz celów i zadań życiowych jest ostatnim ważnym czynnikiem decydującym o znaczeniu twórczości w doświadczeniach autobiograficznych. Jednostka kształtuje ten projekt dzięki refleksji i podsumowaniu własnych przeszłych doświadczeń i poprzez określanie poziomu swojego zadowolenia z życia.

Słowa kluczowe: autokreacja, twórczość, transgresja, projektowanie przyszłości, narracyjna tożsamość, wielość interpretacji, kryzysy, zmiany, rozwój osobisty.

\section{Autobiography as self-creation. The creative aspects of autobiographical thinking in adults education}

Summary: In my article I assume that autobiographical activity is a form of self-creation. Improving autobiographical thinking in adult education may influence the shaping of their creative attitudes towards everyday tasks and problems. Creative elements are present in autobiographical activities because of the possibility of different interpretations of the same life events. These differ-

* Akademia Humanistyczno-Ekonomiczna w Łodzi, Katedra Dydaktyki Ogólnej i Psychodydaktyki Twórczości, 90-222 Łódź, ul. Rewolucji 1905 r. nr 64. 
ing and diverse interpretations are malleable and can help a person to cross their own schemas in thinking. Moreover, a process of constructing one's own life story is based on the use of „biographical fantasy" and elements of fiction. That allows you to identify the different perspectives of self story. During the life story reconstruction process an individual creates their own narrative identity that assumes the possibility of changes of a personal image over time. A reflective project of one's own future and future life goals and objectives is the last important factor determining the importance of creativity in the autobiographical experiences of a person. An individual forms this project due to reflection and summary of their past experiences, as well as through determining/defining the level of the satisfaction with life.

Keywords: auto creation, creativity, transgression, project of future, narrative identity, reflectivity, multiple interpretation, crisis, changes, personal development.

Przedmiotem moich zainteresowań jest poszukiwanie związków pomiędzy działalnością biograficzną i myśleniem autobiograficznym a kształtowaniem postaw twórczych i rolą twórczości w edukacji osób dorosłych. Zakładam, że kształcenie biograficzne powinno uwzględniać rozwój twórczy osoby, wspomagać jej możliwości radzenia sobie w sytuacjach zmiany, kryzysu, momentach przełomu. Elementy twórczości przejawiają się w myśleniu autobiograficznym w różnych ujęciach. Uznaję, że przede wszystkim aktywność twórcza ujawnia się poprzez:

- możliwość różnych interpretacji wydarzeń życiowych (plastyczność interpretacji) i przekraczanie własnych schematów myślowych;

- konstruowanie własnej opowieści o życiu, które łączy się z wykorzystaniem elementów fikcji i „fantazji biograficznej”, pozwala zobaczyć swoją historię z innej perspektywy (np. poprzez odwoływanie do metafor pomagających uchwycić ogólny sens opowieści, poszukiwać nowych znaczeń, patrzeć wieloaspektowo na wydarzenia);

- kształtowanie narracyjnej tożsamości (zmieniającej się w czasie) i własnego obrazu ,ja";

- refleksyjne projektowanie wizji własnej przyszłości i określanie zadań do realizacji.

W artykule podkreślam, że aktywność biograficzna jest formą autokreacji, gdyż poprzez interpretację wydarzeń życiowych człowiek określa samego siebie, nadaje sens swoim przeszłym doświadczeniom, konstruuje i rekonstruuje plany, projekty i cele związane z oczekiwaną przyszłością.

Działania autobiograficzne łączą się z porządkowaniem zdarzeń i wspomnień z przeszłości, dokonywaniem pewnych podsumowań, bilansowaniem. Nie jest to jednak proces ukierunkowany tylko na rejestrowanie obiektywnych faktów z życia, ale ujawnia osobiste interpretacje zdarzeń. Te interpretacje stanowią przedmiot analizy w badaniach biograficznych (za: Lalak, 2010). Przedstawianie własnej historii łączy się często ze zmianą swoich wyobrażeń o własnym życiu i odkrywaniem nowych możliwych sposobów wyjaśnienia tych samych sytuacji z życia. Wspominanie nie jest procesem biernego odtwarzania, ale raczej łączy się 
z wyborem tego, co istotne, tworzeniem pewnej wizji własnej przeszłości. Aktywność autobiograficzna traktowana może być jako autokreacja, zawiera bowiem elementy twórcze. Wiąże się z refleksyjnym odniesieniem się do przeszłości, określaniem własnego ,ja”, projektowaniem przyszłości i planowaniem nowych zadań. Zakłada odnajdywanie nowych punktów widzenia, gdyż rekonstruowanie opowieści o życiu, a także badanie biografii nie muszą być realizowane według pewnego przyjętego schematu, ale są odniesieniem do osobistego projektu życia danej osoby, zmieniającym się pod wpływem nieoczekiwanych zdarzeń i momentów przełomowych.

Momenty przełomowe są inaczej momentami granicznymi, które wymagają wychodzenia poza własną rutynę, adaptację w sytuacji zmiany. Łączą się z potrzebą przekształceń w sposobie myślenia i działania, poszukiwaniem nowych wartości i zadań. W sytuacjach przemian życiowych znaczenia nabiera rozwijanie postawy twórczej, zakładającej elastyczność osoby w różnych okolicznościach. Większa elastyczność, jak pisze Bauman, stanowi sposób na niepewność wynikającą z życia w nieprzewidywalnym świecie (Bauman, 2007, s. 20). Łączy się ona $\mathrm{z}$ refleksyjnością i kreatywnością, otwartością na ryzyko, ale także z gotowością na ponoszenie strat. Refleksja i autorefleksja z kolei umożliwia autokreację, modyfikację sztywnych przekonań, przekraczanie samego siebie w działaniu, uświadamia nowe możliwości rozwoju. Wyjątkowość współczesnych autobiografii polega zatem na ujawnianiu tego, co indywidualne i cenne w życiu jednostki, na docieraniu do jej twórczych możliwości i zasobów autokreacyjnych.

\section{Znaczenie twórczości i autokreacji w indywidualnej biografii}

Zachodnia tradycja antropologii filozoficznej od dawna podkreśla ludzką zdolność do autokreacji, czyli „nadawania sobie kształtu”. Ujawnia się to zwłaszcza w egzystencjalnym nurcie myślenia o człowieku, gdzie jest on ujmowany raczej jako proces niż substancja. Natomiast psychologia narracyjna opisuje doświadczenia własnego istnienia jako procesu, posługując się metaforami podróży czy wędrówki. Nieodłącznym elementem jest zmiana samego siebie zachodząca w czasie (Sikora, 2008, s. 103). Autokreacje wiążą się, zdaniem Schulza, z samorozwojem. Człowiek nie jest twórczy jako profesjonalny artysta, ale jako osoba, jako indywidualne ,ja”. Tworzywem staje się całe życie człowieka i jego osobowość (Schulz, 1990, s. 42). Człowiek tworzy idealny obraz samego siebie, a następnie realizuje go przez całe życie. Autokreacja obejmuje całokształt zadań człowieka, określanie siebie i kierowanie biegiem swojego życia (za: Szmidt, 2007, s. 131).

Twórczość jest pojęciem zbliżonym do autokreacji, choć nie można tych terminów utożsamiać. Twórczość, zdaniem Suchodolskiego, może wyrastać z prze- 
szłości jako jej dopełnienie albo nowa interpretacja (Suchodolski, 1976). Człowiek jest zatem twórczy, gdy nie ogranicza się do powtarzania, naśladownictwa, formułuje swój własny obraz rzeczywistości (Szmidt, 2007, s. 60). Twórczość wyraża się w stylu życia człowieka, jest też kategorią życia trudnego, wiąże się z ryzykiem, niepewnością, wychodzeniem poza oczekiwania społeczne (Suchodolski, 1983, s. 164-165). Każde działanie człowieka wykraczające poza prostą recepcję jest twórczością (Kukiełczyńska, 2000, s. 53). Twórczość zapobiega kryzysom egzystencjalnym (Szmidt, 2007, s. 79). Z względu na to, że pozwala ona na aktualizację zainteresowań i zdolności umożliwia człowiekowi spełnianie się w codziennych działaniach. Helena Radlińska stwierdza, że każdy jest współtwórcą życia, twórcą nowych wartości. Człowiek musi się zdobyć na najtrudniejszą ze sztuk, sztukę ksztaltowania życia. Twórczość odnosi się zatem nie tylko do wybitnych działań, ale także do aktywności codziennej (Radlińska, 1961, s. 366).

Należy podkreślić, że twórczość jest zjawiskiem niejednoznacznym, wieloaspektowym, jej granice są nieostre (Kozłowski, 1998, s. 60-61). Może się przejawiać $\mathrm{w}$ różnych sferach życia. Wiąże się z wytwarzaniem dzieł, ale także z aktywnością codzienną, dotyczy nieszablonowego stosunku do zdarzeń i doświadczeń, kształtowania określonego stylu życia. Ujawnia się poprzez otwartość, ciekawość, oryginalność, nonkonformizm, niekonwencjonalne podejściem do problemów (poziom osobowy, personalny), a na poziomie przedmiotowym łączy się przede wszystkim z nowością i oryginalnością. Twórczość wyrażana jest w nowych koncepcjach, pomysłach, ideach czy postawach. Dotyczy kontekstu społeczno-kulturowego jak i aspektu podmiotowego (Kozłowski, 1998). Wiąże się ze zmianą, wprowadzaniem nowych wartości, przekształcaniem tego, co już powstało.

Roman Schulz stwierdza, że w społeczeństwie nowoczesnym twórczość zyskuje ważną rangę i znaczenie, odnosi się do aspektu pracy, życia, jak również wpływa na ludzi, zmieniając ich działania i osobowość. W każdej dziedzinie życia ludzkiego następuje przyspieszenie rozwoju aktywności twórczej. Społeczeństwa nowoczesne stwarzają coraz lepsze warunki sprzyjające rozwijaniu postaw i zachowań twórczych (Schulz, 1990). Aktywność twórcza ulega jednak coraz większemu zróżnicowaniu: odnosi się do pracy, sztuki, kultury, ale także przejawia się w dążeniach autokreacyjnych zmieniających się ludzi (za: Szmidt, 2007, s. 129).

Autokreacja łączy się zatem z możliwościami osoby wpływania na to, kim się jest, to forma sterowania własnym rozwojem. Może polegać na tworzeniu pewnych wyobrażeń na swój temat, koncepcji siebie, ale także na przekraczaniu własnych granic (Kozielecki, 1976). Człowiek bowiem nie zadawala się tym, kim jest, chce wiedzieć więcej, umieć więcej, rozumieć pełniej sens swojego życia. W związku z tym kształtuje projekty osobiste i zadania pozwalające mu na własny rozwój. Twórczość rozumiana jako autokreacja pozwala na optymalizację jakości życia, gdyż umożliwia przezwyciężanie przeszkód na drodze do samorealizacji (Konieczna, 2004, s. 26). 
Wedle psychologii humanistycznej twórczość stanowi podstawę samorealizacji, wpływa na harmonijny rozwój człowieka. Twórczość jest wartością nadającą życiu sens, gdyż wzbogaca i intensyfikuje rozwój jednostki. Twórczość postrzega się jako otwartą postawę wobec świata i nowych doświadczeń, ale również jako styl życia wyrażający się w spontanicznej ekspresji. W związku z tym wartościowe staje się przede wszystkim autentyczne i spełnione życie, pozytywne relacje z innymi, umiejętność realizowania stawianych sobie celów i zadań. Dzięki ekspresji własnej w procesie twórczym człowiek dojrzewa i realizuje siebie. Głównym źródłem twórczości, zdaniem Abrahama Maslowa, są tendencje człowieka do samourzeczywistnienia się i pełnego rozwijania własnych możliwości (Maslow, 2006). Twórczość zdaniem Rogersa wynika z tendencji do samorealizacji, do stawania się tym, czym czlowiek może być. Akt twórczy jest naturalnym zachowaniem człowieka, pojawiającym się wówczas, gdy człowiek jest otwarty na wszystkie wewnętrzne i zewnętrzne doświadczenia (Rogers, 1961, s. 347-359). Aspekt autokreacji ujawnia się zatem w kontekście doświadczeń życiowych. Z perspektywy psychologii humanistycznej istotne są codzienne działania człowieka, jego wybory i decyzje i to, kim on się staje. Postawa twórcza to zatem szczególna postawa otwartości wobec ludzi, życia i wobec siebie takiego, jakim się jest naprawdę (Fromm, 1959, s. 44-54). Twórczość wiąże się z autentycznością, wyrażającą się w akceptacji samego siebie i dzięki temu umożliwia kształtowanie swojego życia niezależnie od narzucanych społecznie schematów. Autentyczne i spełnione życie jest wyrazem twórczych możliwości człowieka.

\section{Potrzeba przekraczania siebie a dezintegracja pozytywna}

Maslow uważał, że przełamywanie granic swoich możliwości jest ważną cechą natury ludzkiej. Samorealizacja łączy się zatem z potrzebą transgresji. Człowiek przekracza siebie, aby być sobą, by lepiej się samorealizować (Maslow, 1971). Według Kozieleckiego znaczenie w aktywności człowieka mają działania przekraczające dotychczasowe granice osiągnięć, są to transgresje o charakterze ekspansywnym i twórczym. Transgresja łączy się z twórczością, człowiek, wykraczając poza typowe granice działania, kształtuje nowe struktury lub niszczy to, co było już ustabilizowane (Kozielecki, 1997, s. 43-60). Transgresje to zajmowanie nowych terytoriów, konstruowanie wynalazków, łamanie stereotypów, zmagania o prawa człowieka, samokształcenie i wyzwalanie się z ograniczeń narzucanych przez kulturę, osobowość czy cywilizację (Kozielecki, 2001). Działania transgresyjne wiążą się z rozwojem i zmianą, z doskonaleniem, ale także z burzeniem pewnych fundamentalnych zasad czy zwyczajów. Transgresje o charakterze twórczym wzbogacają codzienne działania, istotne są w sytuacjach przełomowych. Należy zaznaczyć, że twórczość łączy z przekształcaniem tego, co już powsta- 
ło, ale także oznacza zmianę siebie lub wizji swojego życia zarówno w aspekcie interpretowania przeszłości, jak i określania przyszłych zadań i planów. Dzięki działaniom transgresyjnym możliwe staje się ponowne określenie siebie, zauważenie nowych perspektyw w swoim życiu i czerpanie satysfakcji z podejmowanych aktywności.

Elementy transgresji związanej z oddziaływaniem człowieka na siebie i własną biografię odnajdujemy w teorii dezintegracji pozytywnej K. Dąbrowskiego, który podkreśla znaczenie twórczości dla rozwoju człowieka w ciągu życia. Dla Dąbrowskiego twórczość jest rezultatem i wyrazem poszukiwań wewnętrznych czlowieka. Teoria dezintegracji pozytywnej zakłada, że człowiek rozwija się pod wpływem okresowych załamań wewnętrznych. Kryzysy czy wstrząsy życiowe są czynnikami związanymi z postawą twórczą. Występująca w życiu jednostki czasowa dysharmonia, niepewność i niestabilność psychiczna czy emocjonalna stanowi potencjał rozwojowy. Dzięki tym procesom może dojść do ponownego scalenia wewnętrznego osoby, czyli do integracji na wyższym poziomie funkcjonowania, nazywanej przez autora integracją wtórną. Biografia osoby naznaczona jest zatem momentami napięć i dylematów wewnętrznych. Rozwój człowieka jest wieloetapowy: poprzez marzenia, projektowanie, planowanie, wahania i konflikty aktywizują się czynniki twórcze (Dąbrowski, 1975, s. 24-27).

Przekraczanie samego siebie, działania transgresyjne w koncepcji Dąbrowskiego dotyczą przede wszystkim wielopłaszczyznowego rozwoju człowieka poprzez wielopoziomową dezintegrację, ale także przekraczanie cyklu biologicznego. Transgresja jest związana ze świadomością doskonalenia siebie, możliwością samowychowania i autoterapii (Limont, 2010, s. 33). Łączy się z procesem dezintegracji i z dążeniem ku celom odległym, wartościom uniwersalnym, integracji wtórnej, zachodzącej na wysokim poziomie funkcjonowania poznawczego.

Momenty załamań, wahania nastroju, konflikty wewnętrzne związane są z poszukiwaniem sensu własnej egzystencji, potrzebą realizacji wyższych wartości, z dezintegracją, która może (ale nie musi) mieć charakter rozwojowy. Rozwój osoby wymaga uzyskiwania autonomii, poszerzania samoświadomości, refleksji i empatii, ale także realizacji uzdolnień i zainteresowań. Łączy się z przechodzeniem przez kolejne etapy rozwoju, nie polega jednak na podporządkowaniu fazowości życia, wyrażającej biologiczne uwarunkowania człowieka (Limont, 2010, s. 45). Należy również podkreślić, że wielopoziomowa spontaniczna dezintegracja jest przeciwstawiana dezintegracji jednopoziomowej, która nie ma charakteru rozwojowego i nie prowadzi do integracji wtórnej, ale raczej do zaburzeń psychicznych.

Wkraczanie na kolejne poziomy nie jest zatem uwarunkowane biologicznie, automatyczne ani sekwencyjne. Dąbrowski odróżnia pojęcie fazy od poziomu rozwoju. Fazy rozwojowe dotyczą wszystkich ludzi, urzeczywistniają rozwojowe uniwersalia. Poziomy dotyczą konkretnych osób i są wyrazem ich indywidualnej normy (Tylikowska, 2000, s. 240-241). Proces kształtowania tożsamości, 
określania samego siebie jest wielopoziomowy, znaczenie mają doświadczenia wewnętrzne osoby i jej gotowość wyzwalania się zarówno od ograniczeń dotyczących determinizmu biologicznego, jak i uwarunkowań społecznych.

Od automatyzmu do świadomego działania, od prymitywizmu do działania skomplikowanego, od determinizmu biologicznego do autodeterminizmu moralnego, od egocentryzmu do alterocentryzmu, od poddawania się wychowaniu do samowychowania, od życia odruchowego do życia świadomego, od zachowania stabilnego, zdeterminowanego biologicznie i przez czynniki zewnętrzne, do zmienności rozwojowej w kierunku zasadniczej stabilizacji jakości centralnych samouświadomionych, samowybranych, samopotwierdzonych i samowychowujących się (Dąbrowski, 1989, s. 56).

Ważną cechą przedstawionych koncepcji jest przekonanie, iż twórczość stanowi rezultat dążeń tkwiących w jednostce, które sprzyjają jej wewnętrznemu wzrostowi. Momenty przełomowe mogą przyczyniać się do podejmowania zadań będących wyzwaniem i mających charakter twórczy, wykraczających poza dotychczasowy biograficzny schemat i rutynę.

\section{Możliwość różnorodnych interpretacji historii życia jako aktywność twórcza}

Rekonstruowanie historii życia przez osobę to nie tylko porządkowanie przeszłości, ale także zalążek przyszłych przeżyć, odkrywanie nowych możliwości i znaczeń, tworzenie ,ja” przyszłego (Giddens, 2001), to interpretacja zakładająca autokreację. Przekraczanie siebie może ujawniać się w stawaniu się świadomym własnych schematów, które towarzyszą interpretacji zdarzeń i w intencjonalnym ich przekształcaniu, co umożliwia głębszą analizę i badanie zmieniających się sposobów kształtowania narracji biograficznych.

Rekonstruowanie opowieści o życiu ma na celu uczenie się, zdobywanie wiedzy o sobie samym, przekraczanie własnych barier, odkrywanie nowych możliwości rozwoju. Bruner stwierdza, że istnieje zależność między życiem i narracją (za: Lalak, 2010, s. 158). Narracje, czyli opowiadania o własnych doświadczeniach i przeżyciach, pozwalają nadawać im porządek, strukturę umożliwiającą postrzeganie życia jako opowieści (Bruner, 1986; Howard, 1991; McAdams, 1999; Sarbin, 1986). Narracyjność wiąże się z interpretacją zdarzeń i pozwala na ich głębsze pojmowanie. Aktywności autobiograficznej towarzyszy zatem potrzeba opowiadania, tworzenia opowieści o sobie i własnych doświadczeniach. Poprzez rekonstrukcję własnej historii człowiek doświadcza zdarzeń życiowych jako uczestnik i jako obserwator (Trzebiński, 2002, s. 27). Pozwala mu to na refleksyjne rozumienie procesów i sytuacji życiowych. Opowiadanie własnej historii innym zmienia schemat interpretacyjny, możliwe staje się zobaczenie jej inaczej, odkrywanie nowych regul interpretacji (Trzebiński, 2002, s. 30). Moż- 
na zatem znaleźć wewnętrzny sens i znaczenie zdarzeń życiowych w kontekście całożyciowego rozwoju. Ponadto rekonstruowanie własnej historii łączy się z samookreśleniem, narracyjnym ujęciem tożsamości, które zakłada, że jest ona otwarta i niedokończona, rozwija się w czasie wraz z doświadczeniami jednostki. Wydarzenia interpretowane różnie na różnych etapach życia nabierają nowych znaczeń i wartości (Keupp, 1999; Straub, 1998). Jednostka, która poprzez osobistą narrację może uwolnić się od kolektywnych wzorów „normalnego życia” czy „normalnej biografii”, staje się twórcą swojego życia (Beck, 2002).

Dzięki procesowi samointerpretacji pojawia się zatem możliwość odejścia człowieka od biografii normalnej do biografii z wyboru i kreatywne określanie swojego dalszego życia. Opowiadając o sobie samych kształtujemy naszą rzeczywistość i nas samych, nadajemy znaczenie faktom z naszego życia, odkrywany nowe wątki, zdarzenia wyjątkowe (Dryll, Cierpka, 2011, s. 28). Narracje pozwalają zdystansować się do problemów życia codziennego. Tworzenie autobiografii, zdaniem Duccia Demetrio, polega na tym również, że człowiek opowiadający o sobie wykorzystuje elementy fantazji i fikcji, w ten sposób również kształtuje określony wizerunek samego siebie (Demetrio, 2000, s. 34-42).

\section{Znaczenie metafory w twórczym interpretowaniu zdarzeń życiowych}

Analiza i badanie biografii może mieć charakter twórczy poprzez odniesienie się do metafor w procesie analizy zdarzeń życiowych.

Interpretacja biografii poprzez przywołanie „metafory podróży” podkreśla różnorodność sposobów opowiadania o życiu, a także rozwojowy charakter działań autobiograficznych i ich znaczenie autokreacyjne. Opowiadanie o życiu może zatem zostać potraktowane jako metafora podróży, która oznacza potrzebę poszukiwań, zmiany, odkrywania siebie, przechodzenia przełomów, kryzysów i przeszkód, które człowiek musi pokonać. Sam Keen podkreśla znaczenie „przebudzenia" człowieka ku życiu wewnętrznemu, w łączności z tym, co transcendentne. Człowiek jego zdaniem musi wyruszyć w „podróż do wewnątrz”. Autor używa tego metaforycznego określenia ukazującego znaczenie samopoznania na głębszym poziomie. „Podróż” ta wiąże się z przekraczaniem wyobrażeń o sobie i zmianą przekonań. Człowiek musi porzucić to, co stare, a także stwarza pozory bezpieczeństwa i odszukać nowe źródła życia, dzięki czemu wejdzie w bogatszą sytuację egzystencjalną i uzyska dojrzałość. Aspekt transgresji w tym ujęciu dotyczy wewnętrznych przełomów dokonujących się w człowieku, który dzięki tej „wewnętrznej podróży” porzuca iluzje, pozory i osobiste mity. Tworzy siebie, dochodząc do zgody z samym sobą, rezygnując z naśladowania innych i konformistycznego dopasowywania się do zewnętrznych okoliczności (Opoczyńska, 
1999, s. 141). Autokreacja łączy się z rozwojem i uzyskiwaniem dojrzałości, gotowością osoby do porzucania naśladownictwa, poszukiwaniem własnej, niezależnej od oczekiwań zewnętrznych drogi życia. Odnajdywanie samego siebie, transgresja ku życiu wewnętrznemu, jest możliwa dzięki rozpoznaniu przez osobę opowieści, którymi żyli jej przodkowie i jak zostały one przekazane kolejnym pokoleniom. Sam Keen nazywa je osobistymi mitami. Mity, jakimi człowiek nieświadomie żyje, ograniczają jego wolność, stają się dla niego ,gettem” bądź „więzieniem”. Sprowadzają się one do utartych i nieświadomych schematów myślenia, odczuwania, postrzegania i działania. Czynią człowieka ,ucieleśnioną funkcją", ma być on kimś określonym i nikim więcej, w pewien oczywisty sposób widzieć świat (Opoczyńska, 1999, s. 142). Odnajdywanie własnej drogi życia wymaga zatem zrozumienia schematów, którymi do tej pory dany człowiek żył i jego bliscy, które określały wzory jego działania. Uświadomienie sobie tych przekazów i przekonań pozwala na ich przekraczanie i zachowanie dystansu wobec oczekiwań innych ludzi i narzucanych przez nich różnych ,powinności”. „Mityczna podróż” do wewnątrz jest rozumiana jako ponowne uporządkowanie własnej przeszłości, wgląd, samorozumienie i reorganizacja doświadczenia, reinterpretacja własnej historii. Istotne w tym procesie jest odwoływanie się do kontekstu całego życia, pozwalające na integralność zdarzeń, uczenie się z własnych doświadczeń (Opoczyńska, 1999).

Sam Keen sugeruje również, aby każda z opowieści, jaką człowiek snuje była opowiadana na wiele sposobów (Opoczyńska, 1999, s. 145-148). Umożliwia to zmianę perspektywy minionych zdarzeń i zrozumienie ich złożoności. Odchodzenie od wcześniej wybranego schematu opowiadania zawiera elementy twórcze, jest poszukiwaniem własnej niepowtarzalności, rozwija własną autonomię i poczucie wpływu na swoje życie. Uczy także elastyczności, wspomaga otwartość osoby na nowe doświadczenia, na rozumienie siebie i innych na głębszym poziomie.

Inną metaforą ujawniającą twórczy charakter opowieści o życiu i zawierającą elementy autokreacji jest metafora książki. Opowieść o życiu według McAdamsa może być konstruowana jako książka, może mieć tytuł i rozdziały, a sam opowiadający traktowany jest jako autor książki o sobie. Sama forma metafory odwołuje do procesu twórczego, zawiera w sobie analogię do działania literackiego i aktywności pisarza. Życie ludzkie według Paula Ricoeura jest niczym tekst literacki (za: Cieciuch, 2011, s. 127). Autor historii decyduje o tym, jak chce przedstawić siebie innym, zakłada się też pewną dowolność i otwartość tego zadania. Twórczy charakter tego procesu podkreśla możliwość różnorodnego przedstawiania tych samych historii dla różnych odbiorców lub na różnych etapach swojego życia (Tokarska, 1999, s. 172-174). Ludzie według McAdamsa poprzez narrację odnajdują w życiu sens i zachowują własną tożsamość (Tokarska, 1999, s. 182). Metafora książki pozwala na wieloaspektowe ujmowanie historii swojego życia, pozwala zauważać jego unikalność i wyjątkowość. Metafora książki według Urszuli Tokarskiej stanowi też bodziec narracyjny dla autora 
opowieści, pozwala mu na zrozumienie głównego przesłania i posiadanej filozofii życiowej, odgrywanych w życiu ról i uwarunkowań rozwoju. Metafora ta pozwala na dokonywanie twórczych przekształceń odnośnie do własnej opowieści (Tokarska, 1999, s. 177). Ważne staje się poszukiwanie różnych wzorców, według których interpretuje się zazwyczaj doświadczenia życiowe. Metafora książki jest też zabiegiem technicznym, pozwalającym na uruchomienie wyobraźni, uchwycenie istoty samego siebie, zobaczenie siebie inaczej i odkrywanie wyjątkowości własnego życia. Metafora książki jest powiązana z określaniem własnej tożsamości, natomiast kryzysy tożsamości znajdują odbicie w potrzebie dokonywania rewizji własnych opowieści. Człowiek, konstruując opowieść o sobie, nie tylko ustosunkowuje się do treści, które wypowiada, ale także charakteryzuje siebie jako podmiot narracji, określa swoje cechy, kreuje obraz siebie jako bohatera tworzonej przez siebie historii życia (Tokarska, 1999, s. 181-186).

\section{Projektowanie przyszłości - znaczenie projektów osobistych}

Opowiadanie historii życia pomaga w pogłębianiu autorefleksji i precyzowaniu własnych myśli. Urszula Tokarska uznaje, że porządkowanie doświadczeń spełnia rolę psychoprofilaktyki egzystencjalnej. Pozwala również na określenie indywidualnych strategii życia i rozwoju (Tokarska, 2011, s. 224). Podnoszenie jakości życia następuje poprzez zrozumienie siebie i swoich uwarunkowań rozwojowych. Człowiek podejmujący autorefleksję nad różnymi obszarami autobiografii konfrontuje się $\mathrm{z}$ własnym doświadczeniem, ale również rozwija $\mathrm{w}$ sobie potrzebę odnajdywania nowych znaczeń i wartości (Tokarska, 2011, s. 225). Elisabeth Kübler-Ross stwierdza, że: „Każda trudność jest szansą. Szansą, aby się wewnętrznie rozwijać" (Kübler-Ross, 2005, s. 37). Narracja zatem jest nie tylko sposobem, w jaki rozumiemy rzeczywistość, ale raczej w jaki tworzymy swój własny obraz świata (Tokarska, 2011, s. 209).

Egzystencjalne problemy człowieka współczesnego dotyczą pojawiania się nowych możliwości życia, szans czy wyborów, jak kariera, wykształcenie, edukacja (Giddens, 2001). Twórczość może mieć zatem znaczenie w samym procesie interpretacji historii życia, zakładając różne ujęcia tych samych zdarzeń i możliwość różnorodnego konstruowania opowieści o życiu. Ten proces ma także znaczenie w realizacji projektów osobistych, ukierunkowanych na działania związane z przyszłością, poprzez aktywne odniesienie do przeszłych zdarzeń osoba uczy się elastyczności, otwartości pozwalającej na aktywne kształtowanie swoich planów, projektów, nowych zadań.

Projekty osobiste przyczyniają się do poprawy funkcjonowania człowieka, mają na celu zmianę i rozwój (Sikora, 2005, s. 75). Projekty osobiste to nie tyle to, co ludzie robią, ale nad czym pracują. W każdym momencie życia osoba jest zaangażowana w pewną liczbę projektów, które mogą być w różnej fazie realizacji. 
Stanowią one sposób organizacji życia, ale jednocześnie powinny uwzględniać zmiany zachodzące w środowisku (Sikora, 2005, s. 73-87). Ważne znaczenie ma poczucie osoby, że jest twórcą tych projektów, że ma swój własny udział w ich modyfikacji i może wpływać na własne życie i jego przebieg.

Twórczość pomaga w głębszym i pełniejszym przeżywaniu świata, w doświadczaniu życia całym sobą - przez intelekt, emocje, wyobrażenia, intuicję, ale także i marzenia. Rozwój osoby wymaga wychodzenia poza automatyczne, stereotypowe formy zachowania, uzyskania samoświadomości, poczucia autentyzmu, spójności autobiograficznej. Człowiek wielokrotnie staje przed wyzwaniem dotyczącym przekonstruowania wcześniejszych zamierzeń związanych z oczekiwaną przyszłością, ale także przed zadaniem nieustannego samookreślania się w nowych, nieprzewidzianych warunkach. Poprzez kształtowanie własnej historii życia i pracy metodą biograficzną ujawniają się możliwości twórcze człowieka. Refleksja nad własną autobiografią pozwala jednostce na odtworzenie własnej historii i na osiągnięcie integracji wewnętrznej. Ważna staje się zamierzona analiza własnej biografii, kształtująca krytyczne odniesienie do tego, z czym się człowiek spotyka na co dzień, jak również umożliwiająca pewną selekcję, czy wybór kierunków działania, zaangażowania i rodzajów aktywności. Praca nad autobiografią opiera się na określaniu własnego pomysłu na to, jak chce się żyć, wymaga dokonywania wyboru wartości i celów spośród wielu możliwych opcji. Opowiadanie własnej historii zmienia schemat interpretacyjny, możliwe staje się zobaczenie jej inaczej, dokonuje się redefinicji historii (Trzebiński, 2002, s. 30).

Przypominanie minionych zdarzeń opiera się na refleksjach dotyczących teraźniejszości, dokonujemy pewnego oglądu życia, kierując się tym, co jest ważne teraz. Demetrio stwierdza, że zajmowanie się autobiografią to odnoszenie się do minionych chwil z uwzględnieniem obecnych przeżyć i doświadczeń. Dlatego też myślenie autobiograficzne może wpływać na proces określania zamierzeń związanych z przyszłością. Dzięki wskrzeszaniu minionego czasu człowiek otwiera się bardziej na otaczający świat, na inne możliwości działania i aktywności (Demetrio, 2000, s. 18). Moment rozpoczęcia opowiadania o sobie można traktować zatem jako nowy etap życia. Tworzenie biografii wiąże się również z dojrzałością. Przejawia się ona jako możliwość dokonywania przemyśleń i zachowania dystansu do pewnych iluzji, własnych wyobrażeń, prowadzi do pewnego pojednania z samym sobą (Demetrio, 2000, s. 21-22).

\section{Podsumowanie}

Opowiadanie o życiu, rekonstrukcja własnej biografii zakłada zatem proces autokreacji, kształtowania siebie, ale także ciągłego poszukiwania, odkrywania nowych wartości i znaczeń. Kształtowanie opowieści, a także jej przekształcanie będące efektem refleksji, może być jednym ze sposobów przyczyniających się do rozwoju 
osobowego człowieka w ciągu życia, pozwala na twórcze kształtowanie własnego życia i spełnienie. Przekraczanie dotychczasowych sposobów doświadczania świata, przełamywanie sztywnych wzorów interpretacyjnych umożliwia bowiem pomyślne przechodzenie przez kryzysy i momenty przełomowe. Pozwala na wielopoziomowy rozwój osoby, integrację wewnętrzną i uzyskiwanie poczucia spójności.

Badanie twórczości w biografii może zakładać analizę wytworów badanej osoby (efektów), na przykład działań artystycznych, naukowych, ale także odnosić się do analizy opowieści o życiu w kontekście aktywności codziennej, a także w aspekcie podmiotowym odnosić się do autokreacji. Badanie biografii odnoszące się do działań autokreacyjnych pozwala uchwycić to, co w danej historii życia jest wyjątkowe, w jaki sposób osoba kształtuje siebie, swój styl życia, ale także jak przekracza własne ograniczenia, jak zmienia się jej koncepcja siebie pod wpływem różnorodnych doświadczeń życiowych. Badanie biografii pod kątem działań autokreacyjnych powinno uwzględniać również dążenia badanych osób do spełniania się, samorealizacji, ujawniania posiadanych zdolności i rozwijania zainteresowań. Badanie biografii mające na celu analizę procesu autokreacji wymaga uwzględnienia momentów granicznych, przełomowych, które zmieniają dotychczasowe drogi życia osób badanych, ale także pozwalają na pełniejsze odkrywanie nowych kierunków działania, nadawanie innych znaczeń własnym doświadczeniom życiowym, porzucanie utrwalonych nawyków postrzegania zdarzeń, przekraczanie siebie (transgresję).

Rekonstrukcja życia w badaniu biograficznym wiąże się także z możliwością przekształcania opowiadanej historii życia przez osoby badane, poszukiwaniem nowych ujęć interpretacyjnych, nowych sposobów prowadzenia narracji biograficznej. Sam proces analizy biografii może wydobywać elementy twórcze życia osoby, ale także sam w sobie być wyzwaniem autokreacyjnym i twórczym dla respondenta. Rekonstrukcja historii życia w badaniu biograficznym może ujawniać lub inicjować twórcze podejście do własnych doświadczeń poprzez poszukiwanie różnych znaczeń, interpretacji i sposobów opowiadania o tych samych wydarzeniach życia. W przełamywaniu schematów interpretacyjnych pomocne może być wykorzystanie metafory czy innych metod inspirujących nowe ujęcie własnej opowieści i ujawniające wieloaspektowy charakter doświadczeń życiowych. Przykładem jest Narracyjna GRA (auto)BIOGRAFICZNA „,W osiemdziesiąt historii do-o-KOLA ŻYCIA ” autorstwa Urszuli Tokarskiej, która może służyć jako narzędzie dydaktyczne, ale także ma zastosowanie w badaniach biograficznych (Tokarska, 2011, s. 219-239). Ważne znaczenie autokreacyjne ma analiza momentów przełomu jako możliwości zmiany, transgresji, przekraczania siebie. W badaniach biograficznych mogą zostać uwzględnione też aspekty dotyczące wyobrażanej przyszłości, stanowiące inspirację dla projektu osobistego i nowych zadań. Refleksja ta może być wywołana poprzez pytania odwołujące się do planów lub marzeń związanych z przyszłością respondentów w kontekście dokonanej przez nich analizy biograficznej (por. Lasocińska, 2011). 
Ujawnianie twórczych aspektów działań autobiograficznych, mających charakter autokreacji, warte jest rozważenia w kontekście badań biograficznych, ale także działań dydaktycznych. Szczególną funkcję spełnia warsztat autobiograficzny, który może zawierać elementy warsztatu twórczości i wspomagać potrzebę własnego rozwoju i autokreacji wśród osób dorosłych (Lasocińska, Wawrzyniak, 2013). Opowieść biograficzna może być rekonstruowana, w sposób tradycyjny opierać się głównie na słowie, ale także być wzbogacana obrazem, dźwiękiem, filmem lub obecnie coraz częściej jako metodę opowiadania stosuje się narracje cyfrowe (inaczej Digital Storytelling), które pozwalają na twórczy i innowacyjny przekaz treści, a także dają możliwość różnorodnego kontaktu z ich odbiorcami poprzez zastosowanie różnych narzędzi multimedialnych i możliwość udostępniania w Internecie (www.tstory.eu). Cyfrowe opowieści wymagają od autora uważnej selekcji dobieranych treści i wykorzystania narzędzi multimedialnych tak, aby zachęcić odbiorców historii do dialogu, refleksji, uczenia się na bazie innowacyjnie rekonstruowanych materiałów autobiograficznych.

\section{Literatura}

Bauman Z., 2007, Ptynne czasy. Życie w epoce niepewności, Wydawnictwo Sic!, Warszawa.

Beck U., 2002, Społeczeństwo ryzyka. W drodze do innej nowoczesności, Wydawnictwo Naukowe „Scholar”, Warszawa.

Bruner J. S., 1986, Actual minds, possible worlds, Harvard University Press, Cambridge.

Cieciuch J., 2011, Między przedmiotem a metodą. Watpliwości związane z koncepcją tożsamości narracyjnej McAdamsa, [w:] E. Dryll, A. Cierpka (red.), Psychologia narracyjna. Tożsamość, dialogowość, pogranicza, Eneteia, Warszawa, s. 111-131.

Dąbrowski K., 1975, Trud istnienia, Wiedza Powszechna, Warszawa, s. 24-27, 31-32.

Dąbrowski K., 1989, W poszukiwaniu zdrowia psychicznego, PWN, Warszawa.

Demetrio D., 2000, Autobiografia. Terapeutyczny wymiar pisania o sobie, Impuls, Kraków.

Dominicé P., 2006, Uczyć się z życia. Biografia edukacyjna w edukacji dorosłych, WSHE, Łódź.

Dryll E., Cierpka A. (red.), 2011, Psychologia narracyjna. Tożsamość, dialogowość, pogranicza, Eneteia, Warszawa.

Fromm E., 1959, The Creative Attitude, [w:] H. H. Andreson (eds), Creativity and Its Cultivation. Adresses Presented at The Interdisciplinary Symposia on Creativity, Harper and Row, New York, s. $44-54$.

Giddens A., 2001, Nowoczesność i tożsamość. „Ja” i spoleczeństwo w epoce późnej nowoczesności, PWN, Warszawa.

Howard G., 1991, Culture Tales: a narrative approach to thinking, cross-cultural psychology and psychotherapy, „American Psychologist”, 46 (3), s. 187-197.

Keupp H. (Red.), 1999, Identitätskonstruktionen. Das Patchwork der Identitäten in Spätmoderne, Reinbek.

Konieczna E., 2004, Arteterapia w teorii i praktyce, Impuls, Kraków.

Kozielecki J., 1997, Transgresja i kultura, Wydawnictwo Akademickie „Żak”, Warszawa.

Kozielecki J., 2001, Psychotransgresjonizm. Nowy kierunek psychologii, Wydawnictwo Akademickie „Żak”, Warszawa.

Kozłowski W., 1998, Zmieniać się, aby być sobą, Instytut Badań Edukacyjnych, Warszawa. 
Kukiełczyńska K., 2000, Proces twórczy jako terapia przez sztukę, Zeszyt Naukowy Akademii Muzycznej we Wrocławiu, nr 72, s. 53.

Kübler-Ross E., 2005, Życiodajna śmierć. O życiu, śmierci i życiu po śmierci, Księgarnia św. Wojciecha, Poznań.

Lalak D., 2010, Życie jako biografia. Podejście biograficzne w perspektywie pedagogicznej, Wydawnictwo Akademickie „Żak”, Warszawa.

Lasocińska K., 2011, Życie poza schematem. Analiza biografii twórców, Wydawnictwo AHE, Łódź.

Lasocińska K., Wawrzyaniak J. K., 2013, Autobiografia jako twórcze wyzwanie. Scenariusze warsztatów biograficznych, Wydawnictwo Akademickie „Żak”, Warszawa.

Limont W. (2010), Teoria dezintegracji pozytywnej jako koncepcja zdolności, [w:] W. Limont, J. Dreszer, J. Cieślikowska (red.), Osobowościowe i środowiskowe uwarunkowania rozwoju ucznia zdolnego, Wydawnictwo Naukowe Uniwersytetu Mikołaja Kopernika, Toruń, s. 33-49.

McAdams D., 1999, Personal narratives and the life story, [w:] L. Pervin, O. John (eds), Handbook of personality: Theory and research, (2 edition), Guilford Press, New York.

Maslow A., 2006, Motywacja i osobowość, tłum. J. Radzicki, Wydawnictwo Naukowe PWN, Warszawa.

Maslow A., 1971, The Farther Reaches of Human Nature, The Viking Press, New York.

Opoczyńska M., 1999, Sama Keena ,mityczna podróż do wewnatrz”, [w:] A. Gałdowa (red.), Wybrane zagadnienia z psychologii osobowości, Wydawnictwo Uniwersytetu Jagiellońskiego, Kraków, s. 139-150.

Radlińska H., 1961, Pedagogika społeczna, Ossolineum, Wrocław.

Sarbin T. (ed.), 1986, Narrative psychology. The storied nature of human conduct, Praeger Press, New York.

Rogers C., 1961, On becoming a person: A therapists view of psychotherapy, Hoghton Mifflin, Boston.

Sikora K., 2005, Zmiana osobowości w ujęciu psychologii projektów osobistych, [w:] A. Niedźwieńska (red.), Zmiana osobowości. Wybrane zagadnienia, Wydawnictwo Uniwersytetu Jagiellońskiego, Kraków, s. 71-101.

Sikora K., 2008, Projekty osobiste - samoregulacja ukierunkowana na rozwój, [w:] A. Niedźwieńska (red.), Samoregulacja w poznaniu i działaniu, Wydawnictwo Uniwersytetu Jagiellońskiego, Kraków, s. 103-121.

Straub J., 1998, Erzählung, Identität and historishes Bewußtein. Die psychologische Konstruktion von Zeit and Geschichte, Frakfurt am Main.

Suchodolski B., 1976, O działalności twórczej, „Studia Pedagogiczne”, t. XXVIII.

Suchodolski B., 1983, Twórczość - rzeczywistość, nadzieje, wątpliwości, [w:] idem, Wychowanie $i$ strategia życia, WSiP, Warszawa.

Szmidt K., 2007, Pedagogika twórczości, GWP, Gdańsk.

Schulz R., 1990, Twórczość - społeczne aspekty zjawiska, PWN, Warszawa.

Tokarska U., 1999, W poszukiwaniu jedności i celu. Wybrane techniki narracyjne, [w:] A. Gałdowa (red.), Wybrane zagadnienia z psychologii osobowości, Wydawnictwo Uniwersytetu Jagiellońskiego, Kraków, s. 169-204.

Tokarska U., 2011, Narracyjna gra (auto)BIOGRAFICZNA „W osiemdziesiat historii do-o-KOŁA ŻYCIA" jako autorska forma wspomagania rozwoju czlowieka dorostego, [w:] E. Dryll, A. Cierpka (red.), Psychologia narracyjna. Tożsamość, dialogowość, pogranicza, Eneteia, Warszawa, s. 219-239.

Tylikowska A., 2000, Teoria dezintegracji pozytywnej Kazimierza Dąbrowskiego. Trud rozwoju ku tożsamości i osobowości, [w:] A. Gałdowa (red.), Tożsamość człowieka, Wydawnictwo Uniwersytetu Jagiellońskiego, Kraków, s. 231-271.

Trzebiński J. (red.), 2002, Narracja jako sposób rozumienia świata, GWP, Gdańsk, s. 16-78.

www.tstory.eu - Storytelling Applied to Training 